\title{
14. TRACE ELEMENT COMPOSITIONS OF LEG 24 BASALTS AND ONE DIABASE
}

\author{
Celeste G. Engel, Scripps Institution of Oceanography, University of California, San Diego, La Jolla, California \\ Elisabeth Bingham, Division of Geological and Planetary Sciences, California Institute of Technology, Pasadena, California \\ and \\ Robert L. Fisher, Scripps Institution of Oceanography, University of California, San Diego, La Jolla, California
}

\section{INTRODUCTION}

At the outset, we planned to add our trace element analyses and petrographic descriptions to the major element analyses of the same rocks presented by Dmitriev (this volume). However, C. Engel was unable to reproduce the values on several elements obtained by Soviet Laboratories on identical samples. Such discrepancies are, in our experience, almost the rule rather than the exception and prompted us to request that the JOIDES Advisory Panel on Igneous and Metamorphic Petrology select several hundred grams of basalt from one DSDP core, preferably from Leg 24 , because of the large amount of basalt obtained, to be split and used as one "standard" or reference sample in petrochemical studies of oceanic basalts. Interlaboratory standardization is a prerequisite to meaningful interpretations and evaluation of the proliferating DSDP analytical data.

In May 1974, the panel rejected our request for a core reference sample, but agreed to consider preparing a large quantity of a low-K dredged basalt. A slightly oxidized and hydrated, low-potassium basalt reference sample is essential for workers and laboratories involved in the Deep Sea Drilling Project. The U.S. Geological Survey "standard" rocks do not include a basalt which is low in potassium, barium, and related elements. The basalt BCR-1 is an alkali-rich basalt which does not approach the composition of oceanic basalts. The supply of the older standard, W-1, is exhausted. W-1 was similar in some ways to oceanic basalts, but the amount of $\mathrm{Ba}$ in $\mathrm{W}-1$ is higher by an order of magnitude than the Ba content of oceanic basalts, and $\mathrm{K}_{2} \mathrm{O}$ in W-1 is about 0.63 weight percent compared to an average $\mathrm{K}_{2} \mathrm{O}$ of about 0.22 in oceanic basalts. There are also major discrepancies in concentrations and ratios of many other elements.

Until use of appropriate oceanic-type standards becomes commonplace, there can be no rigorous comparisons between basalts cored and dredged in the world oceans, whether from mid-ocean ridges, scarps, basins, trenches, or other major tectonic features.

Emission spectrographic analyses for selected trace elements and for $\mathrm{Ti}$ and $\mathrm{Mn}$ were carried out by Elisabeth Bingham at the California Institute of Technology on portions of basaltic rocks cored at five sites: one well within the Gulf of Aden, one just outside the gulf, and three in the western Indian Ocean. In addition, brief petrographic descriptions are given for each sample analyzed. Finally, we have attempted to relate the trace element composition of these basalts to emission spectrographic analyses of dredged basalts.
The drilled localities of Leg 24 where basaltic rocks were encountered and sampled are shown in Figure 1, abstracted from a much more detailed map prepared by Fisher prior to Leg 24. Figure 1 includes the north-south-trending Central Indian Ridge, north to Carlsberg Ridge and west to the African coast. The deep, sedimented Somali Basin forms a broad depression between the mid-oceanic ridges and Somali/Kenya.

Our interest in the igneous rocks of the western Indian Ocean dates back to publications commencing in 1965, and work continues on the rocks from the Central and Southwest Indian Ridges (Engel et al., 1965; Fisher et al., 1968; Engel and Fisher, 1969; Fisher and Engel, 1970; Fisher et al., 1973; Engel and Fisher, in preparation).

\section{SITE 231: GULF OF ADEN, $70 \mathrm{~km}$ NORTH OF SOMALIA}

At Site 231, near the base of the slope off northern Somalia and well within the Gulf of Aden, Glomar Challenger cored 17.5 meters into very fine-grained vesicular flows of basalt. These basalts contain abundant acicular, radiating masses of plagioclase set in a dark, glassy groundmass. The groundmass is altered, in part to palagonite, and is strained and partially altered by hydrated iron oxides. Samples 231-64-1(2) and 231-64-3(3) are, respectively, about 13.1 and 17.4 meters, below the top of the basaltic flows. At these depths within the flows, vesicles up to $0.5 \mathrm{~mm}$ in diameter are numerous and round (Figure 2). Most vesicles are filled with zeolites and calcite.

The basalts from Site 231 are the only rocks from Leg 24 that contain measurable amounts of lead (24 and $42 \mathrm{ppm}$, Table 1). All of the other samples from Leg 24 contain considerably less than $15 \mathrm{ppm} \mathrm{Pb}$. The basalts from the Gulf of Aden also contain more $\mathrm{Ba}$ (31 and $16 \mathrm{ppm}$ ) than basalts cored farther from continental margins. All of the other trace elements and titanium are within the general range of composition reported for oceanic tholeiites (Engel et al., 1965; Melson and Thompson, 1971; Engel and Engel, 1971). We assume that the widespread alteration to palagonite and the mineral fillings in vesicles may account for the larger amounts of $\mathrm{Ba}$ and $\mathrm{Pb}$. The basalts from Site 231 are not "transitional" types, intermediate between low-K tholeiite of oceanic ridges and the alkali olivine basalts common to islands. Of course, we cannot rule out the possibility that the basalts from the Gulf of Aden are contaminated by continental material. 


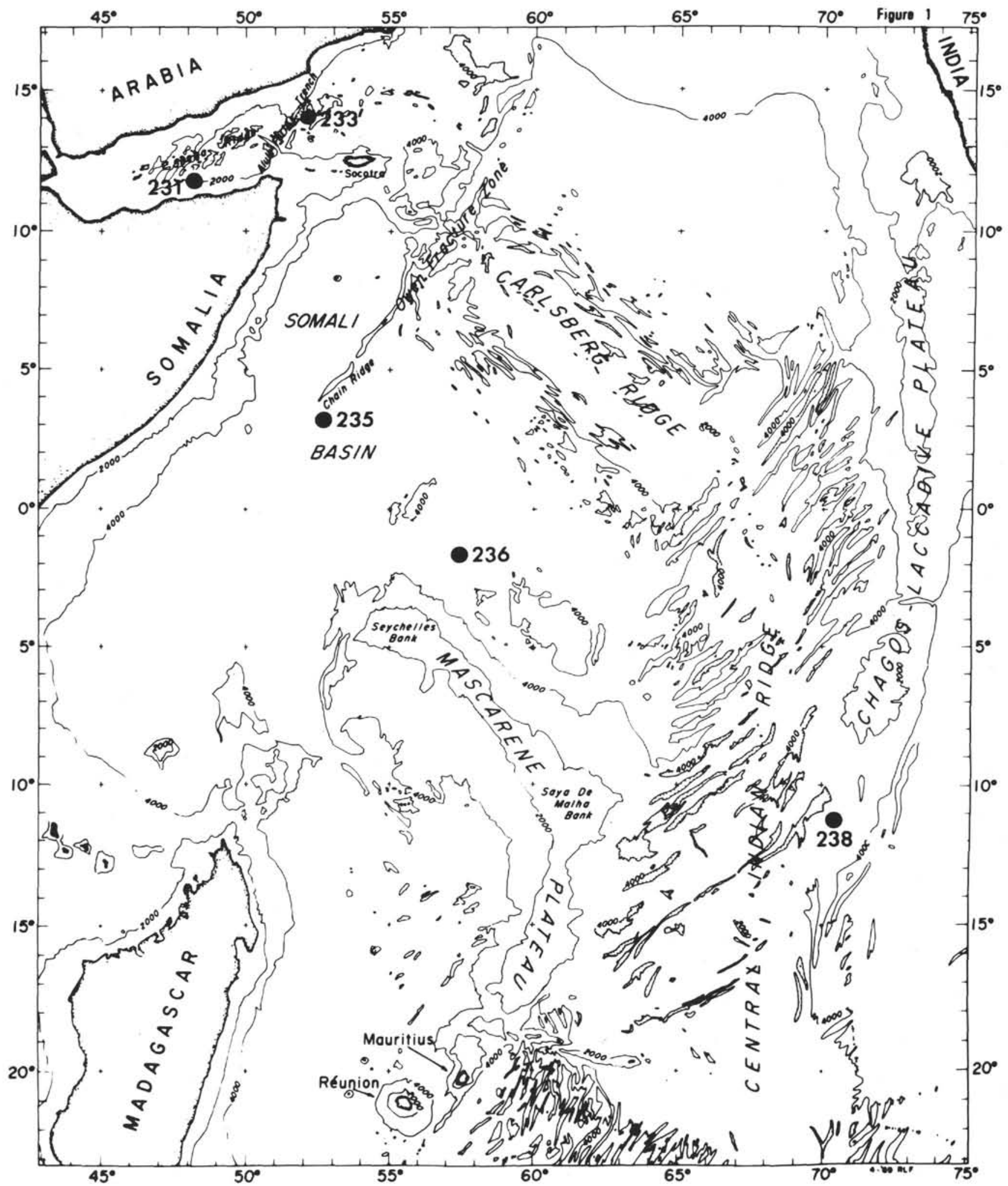

Figure 1. Index map; Leg 24, western Indian Ocean. Sites marked on the map are drilled holes which encountered and recovered basaltic rock. 


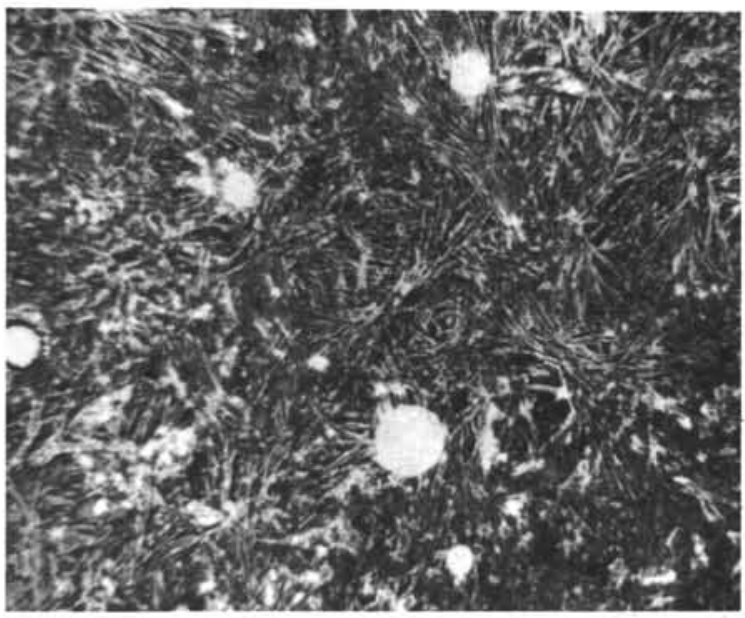

A 231

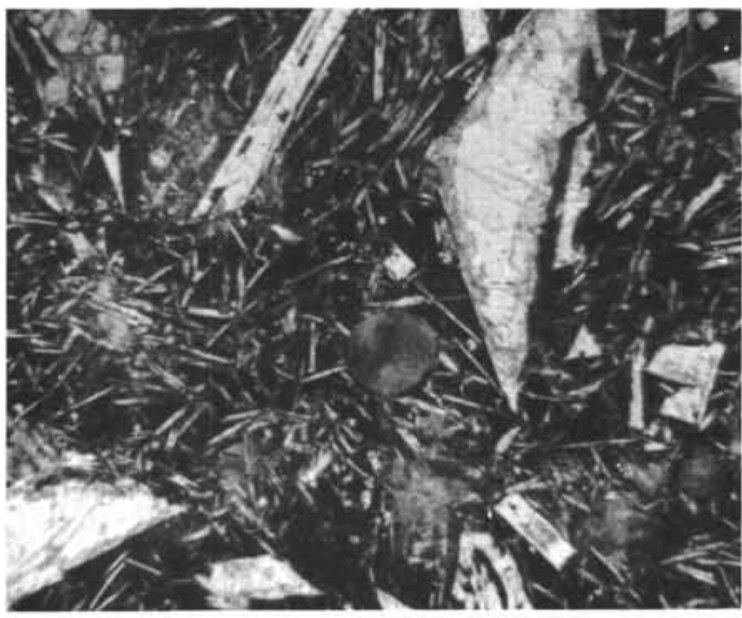

C $\quad 235$

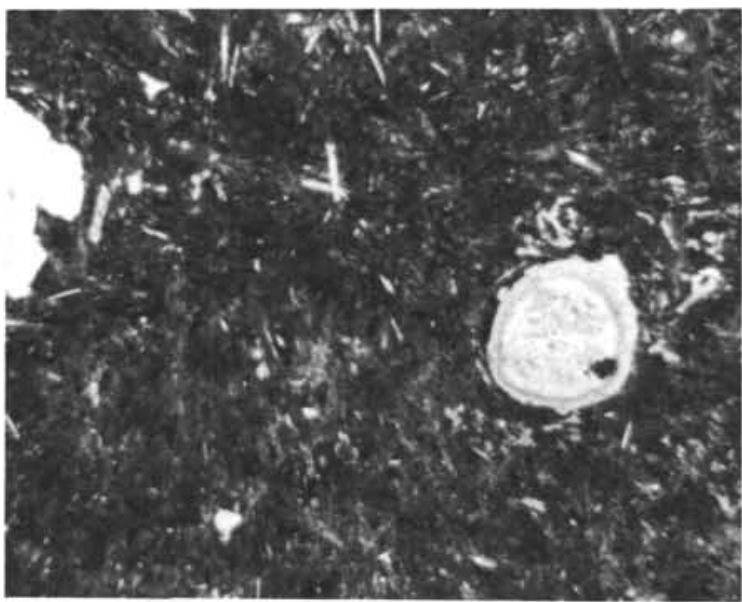

$\mathrm{E}$

236

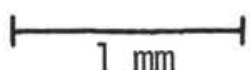

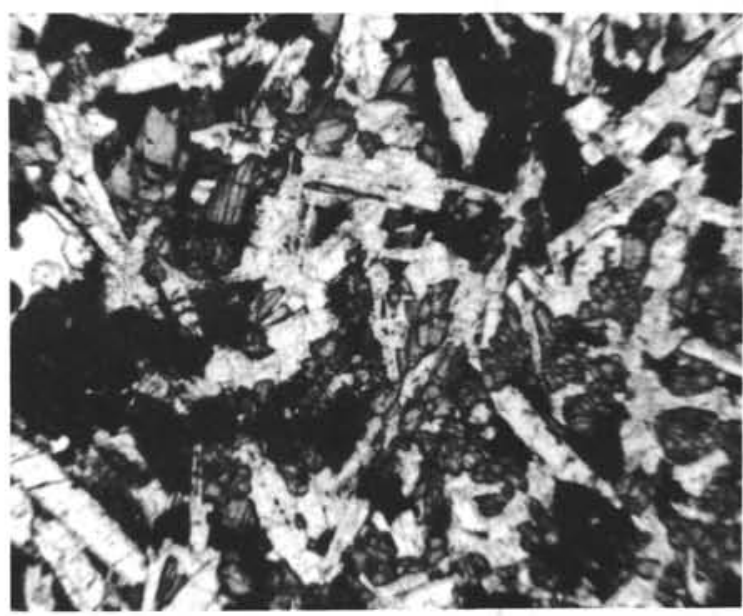

B

$233 \mathrm{~A}$

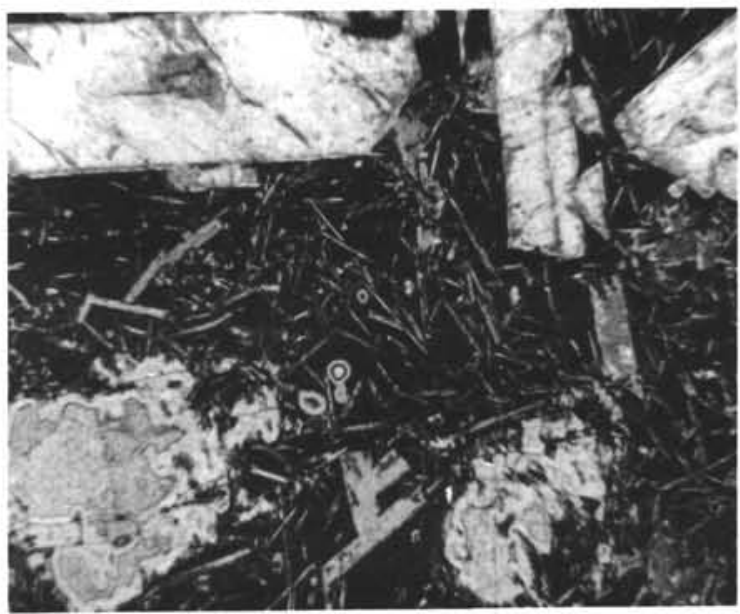

D

235

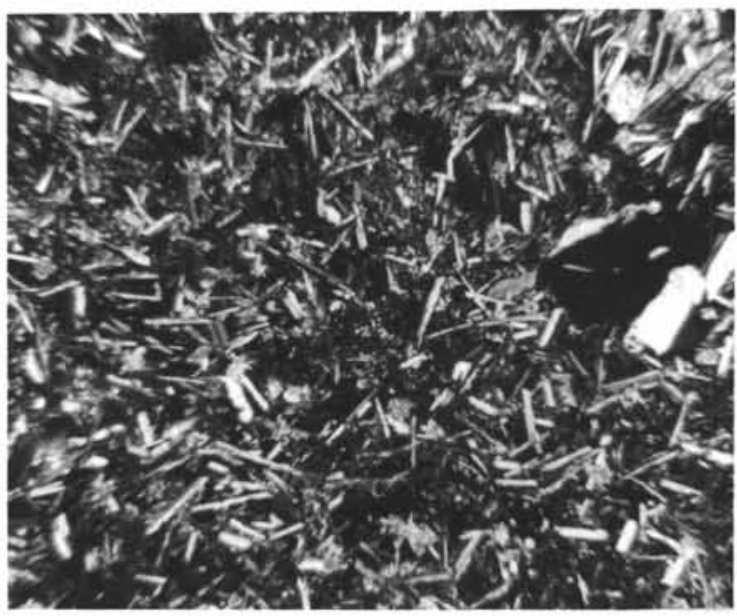

$\mathrm{F}$

238

Figure 2. Photomicrographs (plane light) of basalts and one diabase sill, Leg 24. (A) Site 231: very fine-grained vesicular basalt. Acicular, radiating crystals of plagioclase in a dark glassy groundmass. Vesicles are round and some are filled with calcite and zeolites. (B) Hole 233A: augite diabase. Much of the augite is altered to chlorite and serpentine minerals. (C) Site 235: porphyritic, plagioclase-rich basalt. Vesicles are round and are filled with alteration minerals (calcite and celadonite). (D) Site 235: plagioclase phenocrysts are partially corroded, resorbed and are laced with blebs of glass. (E) Site 236: slightly porphyritic augite-plagioclase basalt. The dark groundmass consists of felted mats of plagioclase and glass. Vesicles are round and are very rare. (F) Site 238: augite-plagioclase basalt. The texture of the groundmass is subdiabasic. Phenocrysts are rare. 
TABLE 1

Emission Spectrographic Analyses of Basaltic Rocks Cored on Leg 24, DSDP Western Indian Ocean

\begin{tabular}{|c|c|c|c|c|c|c|c|c|c|c|c|c|c|c|c|}
\hline Samplea & $\mathrm{Ba}$ & Co & $\mathrm{Cr}$ & $\mathrm{Cu}$ & $\mathrm{Ga}$ & $\mathrm{Mn}$ & $\mathrm{Ni}$ & $\mathrm{Pb}$ & $\mathrm{Sc}$ & $\mathrm{Sr}$ & $\mathrm{Ti}$ & V & $\mathrm{Y}$ & $\mathrm{Yb}$ & $\mathrm{Zr}$ \\
\hline $231-64-1(2)$ & 31 & 51 & 260 & 89 & 14 & 1400 & 220 & 24 & 46 & 180 & 6400 & 220 & 45 & 4 & 56 \\
\hline $231-64-3(3)$ & 16 & 52 & 250 & 88 & 15 & 1200 & 200 & 42 & 42 & 210 & 6100 & 200 & 38 & 3 & 48 \\
\hline $233 \mathrm{~A}-13-1(2)$ & 9 & 43 & 51 & 81 & 16 & 1400 & 36 & 2 & 46 & 200 & 8500 & 250 & 38 & 4 & 77 \\
\hline $235-19-1(10)$ & 9 & 37 & 430 & 48 & 14 & 1100 & 130 & 2 & 36 & 170 & 3700 & 180 & 25 & 2 & 36 \\
\hline $235-20-2(21)$ & 3 & 47 & 440 & 67 & 14 & 950 & 220 & 3 & 37 & 180 & 4500 & 180 & 28 & 2 & 41 \\
\hline $235-20-4(21)$ & 3 & 54 & 480 & 71 & 13 & 1100 & 330 & 5 & 39 & 150 & 4700 & 170 & 29 & 2 & 45 \\
\hline $235-20-5(8)$ & 3 & 48 & 460 & 70 & 13 & 1100 & 230 & 3 & 33 & 180 & 3800 & 170 & 24 & 4 & 39 \\
\hline $236-33-3 A(4)$ & 7 & 75 & 280 & 120 & 13 & 780 & 300 & 11 & 53 & 100 & 3300 & 200 & $<20$ & 4 & 29 \\
\hline $236-35-1(1)$ & 5 & 43 & 260 & 130 & 14 & 780 & 72 & 3 & 43 & 180 & 2100 & 210 & $<20$ & $\sim 2$ & 32 \\
\hline $236-36-2(7)$ & 5 & 46 & 250 & 110 & 12 & 1100 & 100 & 1 & 48 & 110 & 2600 & 180 & $<20$ & 3 & 27 \\
\hline $238-55-2(3)$ & 6 & 48 & 300 & 110 & 13 & 1000 & 160 & 9 & 55 & 130 & 3700 & 210 & 36 & 3 & 40 \\
\hline $238-57-3(7)$ & 8 & 47 & 300 & 110 & 15 & 1100 & 85 & $13 ?$ & 52 & 170 & 5800 & 240 & 40 & 4 & 48 \\
\hline $238-59-1(3)$ & 8 & 53 & 310 & 120 & 15 & 1100 & 98 & 2 & 59 & 170 & 6500 & 270 & 47 & 4 & 54 \\
\hline W-1 (gabbro) & 240 & 52 & 140 & 110 & 16 & 1200 & 79 & n.d. ${ }^{b}$ & 44 & 260 & 5600 & 260 & 36 & 3 & 84 \\
\hline
\end{tabular}

Note: Analyst: Elisabeth Bingham, California Institute of Technology, Pasadena, California.

aNumbers in parentheses are sequence of rock samples in the section.

$b_{\text {n.d., not determined. }}$

\section{SITE 233A: EAST MARGIN OF THE ALULA-FARTAK TRENCH}

A diabase dike or sill was cored off the northern flank of the Alula-Fartak Trench (fracture zone). Drilling rates suggest that this intrusive body is about 4.5 meters thick. About 2.6+ meters of rock were recovered from the upper(?) part of the sheet. The rock is a medium-grained augite diabase, with much of the augite altered to chlorite and serpentine minerals. The plagioclase is labradorite and is fresh. A microphotograph of a typical section of diabase is shown in Figure 2. Amounts of $\mathrm{Cr}(51 \mathrm{ppm})$ and $\mathrm{Ni}$ $(36 \mathrm{ppm})$ are anomalously low in this rock (233A-13-1(2), Table 1) as compared with the average of basaltic flows (Table 2).

\section{SITE 235: SOMALI BASIN, JUST SOUTHEAST OF CHAIN RIDGE}

All of the rocks recovered at this site are porphyritic plagioclase-rich basalts. The plagioclase occurs as single, corroded, and resorbed phenocrysts and as clusters of phenocrysts (glomeroporphyritic texture). Plagioclase in the groundmass forms as radiating clusters immersed in a glassy matrix (Figure 2). Much of the groundmass is altered to palagonite. This basalt contains rare, round vesicles which are rimmed by green palagonite (celadonite?) and filled with calcite. Sample 235-19-1(10), about midway in the basaltic section cored (apparently $19.5 \mathrm{~m}$ below the sediment-basalt interface), contains more $\mathrm{Ba}$ and less $\mathrm{Co}$, $\mathrm{Cu}$, and $\mathrm{Ni}$ than the underlying basalt of this site. These differences in trace element composition may be due to the extreme alteration of the glassy groundmass or, as in the instance of variations in barium, to the reduced number of feldspar phenocrysts.

Three samples from deeper parts cored at Site 235 (Table 1) contain about 40 percent plagioclase as phenocrysts, with scattered phenocrysts of augite set in a tachylitic groundmass. Many of the plagioclase phenocrysts are partially corroded, resorbed, and are laced with blebs of glass. Vesicles are round and filled with calcite. Thin veins of calcite also fill cracks in the basalts. In these three deeper samples at Site 235, Ba averages $3 \mathrm{ppm}$ and $\mathrm{Zr}$ about 42
TABLE 2

Average Trace Element

Analyses of Leg 24 Basalts

Compared With Basalts Dredged

From the Central Indian Ridge-

Southwest Indian Ridge and From

Ridges in the Atlantic and Pacific Oceans

\begin{tabular}{lrrrr}
\hline & $1^{\mathrm{a}}$ & $2^{\mathrm{b}}$ & \multicolumn{1}{c}{$3^{\mathrm{c}}$} & $4^{\mathrm{d}}$ \\
\hline $\mathrm{Ba}$ & 6 & 21 & 14 & 12 \\
$\mathrm{Co}$ & 50 & 34 & 32 & 41 \\
$\mathrm{Cr}$ & 350 & 370 & 297 & 296 \\
$\mathrm{Cu}$ & 95 & 84 & 77 & 87 \\
$\mathrm{Ga}$ & 14 & 21 & 17 & 18 \\
$\mathrm{Ni}$ & 170 & 100 & 97 & 123 \\
$\mathrm{Sc}$ & 45 & n.d. & 61 & n.d. \\
$\mathrm{Sr}$ & 150 & 130 & 130 & 131 \\
$\mathrm{~V}$ & 200 & 225 & 292 & 289 \\
$\mathrm{Y}$ & $25 ?$ & 40 & 43 & 43 \\
$\mathrm{Yb}$ & 3 & 4 & 5 & n.d. \\
$\mathrm{Zr}$ & 39 & 88 & 95 & 100 \\
\hline
\end{tabular}

Note: n.d. not determined.

aAverage of 10 samples from Sites 235, 236, and 238 (Table 1).

b Average of 16 basalts from 12 dredge stations on the Central Indian RidgeSouthwest Indian Ridge (Fisher and Engel, 1970, p. 671 ; also our unpublished data).

$\mathrm{c}_{\text {Average of five stations in the Pacific }}$ and five stations in the Atlantic oceans (Engel et al. 1965).

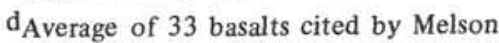
and Thompson (1971) from the literature.

ppm. These values are the lowest amounts of $\mathrm{Ba}$ and $\mathrm{Zr}$ obtained in oceanic basalts recovered by drilling or dredging (Tables 1 and 2).

Site 235 is located at $03^{\circ} 14^{\prime} \mathrm{N}, 52^{\circ} 41^{\prime} \mathrm{E}$ about $1100 \mathrm{~km}$ due north of basaltic rocks dredged by SIO's Argo on the Amirante Ridge at $06^{\circ} 40^{\prime} \mathrm{S}, 52^{\circ} 53^{\prime} \mathrm{E}$. We reported trace element compositions for two Amirante Ridge basalts which, from initial attempts at K-Ar dating, may be about the same age as the basalts cored at Site 235 (Fisher et al., 1968). The dredged basalts contain: $\mathrm{Ba}, 9 ; \mathrm{Co}, 34 ; \mathrm{Cr}, 230$; 
$\mathrm{Cu}, 160 ; \mathrm{Ga}, 15 ; \mathrm{Ni}, 95 ; \mathrm{Sc}, 51 ; \mathrm{V}, 300 ; \mathrm{Y}, 25 ; \mathrm{Yb}, 4$; and $\mathrm{Zr}$, 40. These older dredged basalts also have very low amounts of $\mathrm{Ba}$ and $\mathrm{Zr}$ and are similar to the average basalt cored at sites on Leg 24 (Table 2).

\section{SITE 236: EASTERN REGION OF THE SOMALI BASIN}

Site 236 is located in the Somali Basin approximately midway between the oceanic ridge and "continental" Seychelles block (Figure 1). Sample 236-33-3A(4) from the upper part of the basalt core at this site, about 0.5 meter below the sediment-basalt interface, is fairly fresh, hence probably younger than basalt encountered at greater depths. The rock is a porphyritic augite-plagioclase basalt with a groundmass of felted mats of plagioclase and glass. Vesicles are round and very rare. Plagioclase phenocrysts comprise about 10 percent of the rock, and augite phenocrysts form about 3 percent. Locally, plagioclase needles in the groundmass are aligned in faint flow patterns.

This sample of an upper flow at Site 236 contains more $\mathrm{Ni}$ and $\mathrm{Cr}$ than two underlying flows-(236-35-1(1) and 236-36-2(7). All of the samples contain less than $20 \mathrm{ppm} \mathrm{Y,}$ and the lowest amounts of $\mathrm{Zr}$ found in any of the basalts, averaging $29 \mathrm{ppm}$ (Table 1).

\section{SITE 238: NORTHEAST END OF ARGO FRACTURE ZONE, ADJACENT TO THE CHAGOS-LACCADIVE RIDGE}

Site 238 was drilled in the sediment-filled northeast part of the Argo Fracture Zone. We have dredged fault-exposed coarse-grained intrusive gabbros, anorthositic gabbros, anorthosites, and peridotites from this cross-fracture (Engel and Fisher, 1969). There was a possibility Site 238 would enter such a complex, but only basalt, in thin to massive layers, was encountered. The igneous pile was penetrated and sampled to a depth of 80.5 meters.

Sample 238-55-2(3) (cored approximately $7 \mathrm{~m}$ below the sediment-basalt contact) is a fine-grained, slightly porphyritic basalt (Figure 2). The groundmass consists of augite and plagioclase. Vesicles are round and are filled with secondary hydrated minerals.

Samples 238-57-3(7) (25.0 m) and 238-59-1(3) (36.4 m) are coarser grained than the shallow sample above. There are scattered phenocrysts of augite and plagioclase. The groundmass is composed of plagioclase and pyroxene. The texture of the groundmass is subdiabasic (Figure 2), and much of the pyroxene in the groundmass is altered.

\section{DISCUSSION}

Table 2 contains the average composition of 9 basalts from Sites 235, 236, and 238 compared with the average composition of oceanic ridge basalts obtained by others (Table 2). The similarities between the averages are striking. Columns 3 and 4 are essentially identical, which raises the question of whether the similarities are real or an artifact.

Leg 24 drilled only three holes in the Indian Ocean basin proper that yielded basalt that may be compared with dredged Central Indian Ridge basalts (Engel and Fisher, 1969). However, several characteristics common to the cored specimens used in this trace element study are of interest:

1) The basalts from Sites 235,236 , and 238 contain little or no visual olivine; most other basalts dredged from the ridge system do contain olivine as phenocrysts.

2) Basalts from these three holes contain vesicles that are round, whereas essentially all flows of dredged basalts contain elongate and irregularly shaped vesicles.

3) Dredged basalts commonly display pronounced flow structure in the groundmass plagioclase. Such alignment is missing to very rare in nine specimens from Sites 235,236 , and 238 , but appears faintly developed in $236-33-3 \mathrm{~A}(4)$. In summary, except for glassy seams and textural variations, these cored materials provide little structural evidence of flowage, while fresh (and even altered) dredged specimens display marked to spectacular contortions, rolls, and squeezeouts.

The basalts from these three holes are similar in composition to oceanic ridge basalts (Table 2). The cored basalts may not have flowed out on hard rock surfaces but rather oozed under shallow layers and "burrowed" into sediments (Christensen et al., 1973). In this way, initially extrusive basalts become intrusive bodies, incorporating to some degree the overlying or confining material. Such seems possible at Site 238 , from evidence cited above. If direct dating is possible on the drilled basalts from Leg 24 , one might guess that the basalts are younger than the paleontological date. Several workers have attempted to date basalts from the Deep Sea Drilling Project by fission track and $\mathrm{Ar}^{40} / \mathrm{Ar}^{39}$ methods and suggest they are younger than the paleontologic date of the superjacent sediments; younger, too, than the "anomaly date" (MacDougall, 1973; Ozima et al., 1973). The mode of emplacement of off-ridge basalts into sediments can give the section the characteristics of both extrusive and intrusive rock.

The deep penetration and good sample recovery at Site 238 permitted examination of fracture patterns, inclusions, and selvages, revealing a number of plications or thin layers bordered by glassy or brecciated zones suggestive of thin, superposed, highly fluid flows. Carbonate sediments in small pods or cracks found in the deepest sections recovered were only moderately recrystallized. Dmitriev and Fisher (this volume, Site Reports) suggest that such calcareous material trickled into openings in cool fractured rock and was buried by subsequent flows. Closer study of the upper major contact between basalt and the Fe-stained, variously discolored, zeolite- and volcanic ash-bearing basal strata (Unit 3 at Site 238) may establish whether the sediment-igneous relationship displayed at Site 238 marks (1) shallow intrusion following rupture of Chagos and Saya de Malha banks or (2) waning stages and passive burial of ridge-type flows, very early in the development of the Central Indian Ridge.

\section{ACKNOWLEDGMENTS}

This study was supported by the National Science Foundation (NSF Grants GA-3244IX, GA-23335, and GA-41183), and the National Aeronautics and Space Administration (Grant 05-009-152). 


\section{REFERENCES}

Christensen, N. I., Frey, F., MacDougall, D., Melson, W. G., Peterson, M.N.A., Thompson, G., and Watkins, W., 1973. Deep Sea Drilling Project. Properties of igneous and metamorphic rocks of the oceanic crust: EOS, Am. Geophys. Union Trans., v. 54, p. 972-981.

Engel, A. E. J. and Engel, C. G., 1971. Mafic and ultramafic rocks: In The sea, vol. IV, new concepts of sea floor evolution, Part One; New York, (Wiley and Sons), p. 465-519.

Engel, C. G. and Fisher, R. L., 1969. Lherzolite, anorthosite, gabbro, and basalt dredged from the Mid-Indian Ocean Ridge: Science, v. 166, p. 1136-1141. in preparation. Ultramafic to granitic rock complexes of the Indian Ocean Ridge System.

Engel, A. E. J., Engel, C. G., and Havens, R. G., 1965. Chemical characteristics of oceanic basalts and the upper mantle: Geol. Soc. Am. Bull., v. 76, p. 719-734.

Engel, C. G., Fisher, R. L., and Engel, A. E. J., 1965. Igneous rocks of the Indian Ocean floor: Science, v. 150, p. $605-610$.
Fisher, R. L. and Engel, C. G., 1970. Lherzolite, anorthosite, gabbro, and basalt dredged from the cross-fractures and rifted zone of the Mid-Indian Ocean Ridge (in Russian): Geokhiimia, v. 6, p. 661-677.

Fisher, R. L., Engel, C. G., and Alexander, E. C., 1973. Preliminary ${ }^{40} \mathrm{Ar}-{ }^{39} \mathrm{Ar}$ studies of Central Indian Ridge gabbros and anorthosites (abstract): EOS, Am. Geophys. Union Trans., v. 54, p. 1220.

Fisher, R. L., Engel, C. G., and Hilde, T.W. C., 1968. Basalts dredged from the Amirante Ridge, western Indian Ocean: Deep-Sea Res., v. 15, p. 521-534.

MacDougall, D., 1973. Fission track dating of oceanic basalts: EOS, Am. Geophys. Union Trans., v. 54, p. 987-988.

Melson, W. G. and Thompson, G., 1971. Petrology of a transform fault zone and adjacent ridge segments: Phil. Trans. Roy. Soc. London, Series A., v. 268, p. 423-441.

Ozima, M., Saito, K., and Joshima, S., 1973. K-Ar, ${ }^{40} \mathrm{Ar} /{ }^{39} \mathrm{Ar}$ dating, and magnetic studies of Leg 7 and Leg 17 basalt samples: EOS, Am. Geophys. Union Trans., v. 54, p. 989. 